\title{
0371. Temporal changes in systemic and renal inflammation and histology in a 72-hour rat model of faecal peritonitis
}

\author{
N Arulkumaran ${ }^{1,2,3^{*}}$, M Sixma ${ }^{1}$, E Ceravola ${ }^{4}, \mathrm{R}$ Unwin $^{2}$, FW Tam $^{3}$, M Singer $^{1}$ \\ From ESICM LIVES 2014 \\ Barcelona, Spain. 27 September - 1 October 2014
}

\section{Introduction}

Mechanisms underlying sepsis-induced acute kidney injury remain uncertain with inflammation and altered haemodynamics being implicated.

\section{Objectives}

To determine temporal changes in systemic and renal inflammation, and histology, in a 72 hour fluid-resuscitated model of sepsis.

\section{Methods}

Tunnelled central venous (for fluid administration) and arterial (for BP monitoring/blood sampling) lines were inserted into male Wistar rats under isoflurane anaesthesia. Sepsis was induced 24h later by i.p. injection of faecal slurry. Fluid resuscitation was commenced at $2 \mathrm{~h}$ post-slurry. Cardiac output was assessed by echocardiography. Animals ( $n=6-8$ per group) were sacrificed at $6,12,24,48$, or $72 \mathrm{~h}$ with kidneys taken for histological section and cytokine (IL-1 $\beta$, IL-10 by ELISA) analysis, and blood samples for renal biochemistry, and pro- (IL-1 $\beta$, IL-6), and anti-inflammatory cytokine (IL-10) analysis by ELISA. Renal histology was assessed by light microscopy for features of tubular injury (dilated tubules, tubular casts, cell necrosis), and cell death using TUNEL stain. Comparison was made against sham-operated controls and naïve animals. Statistics were performed using ANOVA and post-hoc Tukey's test. Values are expressed as means \pm standard deviation.

\section{Results}

Sham animals had values similar to naive animals. In septic animals, serum IL- 6 and IL- $1 \beta$ were maximal at

Table 1 Cytokine values

\begin{tabular}{|c|c|c|c|c|c|c|}
\hline Group & $\begin{array}{l}\text { Creatinine ( } \mathrm{\mu mol} / \\
\text { l) }\end{array}$ & $\begin{array}{l}\text { Serum IL-1 } \beta(p g / \\
m L)\end{array}$ & 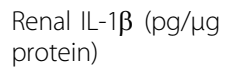 & $\begin{array}{l}\text { Serum IL-10(pg/ } \\
\text { mL) }\end{array}$ & $\begin{array}{l}\text { Renal IL-10 (pg/ } \mu \mathrm{g} \\
\text { protein) }\end{array}$ & $\begin{array}{l}\text { Serum IL-6(pg/ } \\
\text { mL) }\end{array}$ \\
\hline Naïve & $23 \pm 2.6$ & $1.0 \pm 0.0$ & $135 \pm 36$ & $24 \pm 30$ & $207 \pm 80$ & $0.8 \pm 0.4$ \\
\hline 6hr Sepsis & $26 \pm 6$ & $1428 \pm 1006$ & $267 \pm 46$ & $3390 \pm 1759$ & $220 \pm 56$ & $36347 \pm 27646$ \\
\hline $\begin{array}{l}12 \mathrm{hr} \\
\text { Sepsis }\end{array}$ & $21 \pm 2.5$ & $1289 \pm 296$ & $260 \pm 57$ & $2939 \pm 1236$ & $89 \pm 58$ & $15217 \pm 13285$ \\
\hline $\begin{array}{l}24 \mathrm{hr} \\
\text { Sepsis }\end{array}$ & $30 \pm 5$ & $1434 \pm 1601$ & $398 \pm 87$ & $4716 \pm 2682$ & $180 \pm 44$ & $8835 \pm 16422$ \\
\hline $\begin{array}{l}48 \mathrm{hr} \\
\text { Sepsis }\end{array}$ & $31 \pm 4$ & $1008 \pm 887$ & $318 \pm 140$ & $3699 \pm 3745$ & $238 \pm 121$ & $144 \pm 172$ \\
\hline $\begin{array}{l}72 \mathrm{hr} \\
\text { Sepsis }\end{array}$ & $27 \pm 5$ & $256 \pm 294$ & $157 \pm 66$ & $1410 \pm 1670$ & $168 \pm 37$ & $163 \pm 333$ \\
\hline
\end{tabular}


6h; this corresponded with the highest core temperature and tachycardia, and the largest drop in stroke volume. By $24 \mathrm{~h}$, serum IL- 6 and IL-1 $\beta$ fell, whereas IL-10 levels peaked; this corresponded to recovery of cardiac function and normalization of core temperature. Renal inflammation (peak renal IL-1 $\beta$ and lowest IL-10) was maximal at $24 \mathrm{~h}$ when serum creatinine also peaked. By $72 \mathrm{~h}$, serum creatinine and IL- $1 \beta$ approached baseline values while renal IL-10 reached its zenith. (Table 1) Acute tubular injury was mild and sporadic, with minimal renal tubular cell death.

\section{Conclusions}

Temporal changes in renal inflammation and dysfunction lag behind changes in systemic inflammation and cardiac dysfunction. Renal dysfunction, as measured by serum creatinine, corresponds to renal inflammation. Cell death does is not a predominant feature, and does not account for the renal dysfunction seen in this sepsis model.

\section{Grant acknowledgment}

NA is supported by the Wellcome Trust

\section{Authors' details}

'University College London, Bloomsbury Institute of Intensive Care Medicine, London, UK. ${ }^{2}$ University College London, Centre for Nephrology, London, UK. ${ }^{3}$ Imperial College London, Department of Nephrology, London, UK. ${ }^{4}$ Major Hospital Niguarda Ca Granda, Intensive Care Medicine, Milan, Italy.

Published: 26 September 2014

doi:10.1186/2197-425X-2-S1-P23

Cite this article as: Arulkumaran et al: 0371. Temporal changes in systemic and renal inflammation and histology in a 72-hour rat model of faecal peritonitis. Intensive Care Medicine Experimental 2014 2(Suppl 1): P23.

\section{Submit your manuscript to a SpringerOpen ${ }^{\mathcal{D}}$ journal and benefit from:}

- Convenient online submission

- Rigorous peer review

- Immediate publication on acceptance

- Open access: articles freely available online

- High visibility within the field

- Retaining the copyright to your article

Submit your next manuscript at $\gg$ springeropen.com 